\title{
THE DEVELOPMENT OF SOCIAL COMPETENCE OF TEACHERS AND STUDENTS: SELF- ASSESSMENT RESEARCH
}

\author{
Genutė Gedvilienė \\ Vytautas Magnus University
}

\begin{abstract}
In today's life, the formation of a new twenty-first century society structure, which is changing people's personal, professional and social conditions of existence, more and more frequent are demands from the public and there is a trend of social competence development. First of all, thinking about the teachers, who often run initiatives, internal motivation, knowledge, sometimes in interaction with students in strengthening the social competence phenomena such as communication and cooperation. It is never too late to improve communication and cooperation culture. The article seeks to reveal the importance of social competence for self-assessment process. The article presents the theoretical background of self-assessment process. In order to reveal social competence, a model which illustrates the parts of social competence such as communication (reciprocity) and cooperation (activity) is presented. That's why teacher-teacher, teacher-student, student-student, student-teacher have been chosen as research subjects who reflect the characteristics of reciprocity and activity in the process of learning. The instrument of the research is a questionnaire. The research participants were 49 Lithuanian teachers, 142 students and 23 Belgian teachers and 86 students.

KEY WORDS: social competence, communication, cooperation, self-assessment.
\end{abstract}

\section{Anotacija}

Šiandien, kuriantis naujai XXI amžiaus visuomenès struktūrai, kuri keičia žmonių asmeninio, profesinio ir socialinio gyvenimo sąlygas, didèja socialinès kompetencijos tobulinimo reikalavimai. Tai ypač aktualu mokytojams, kurie ịgyvendina įvairias iniciatyvas kartu su mokiniais ir taip bendraudami bei bendradarbiaudami tobulina socialinę kompetenciją. Puoselèti bendravimo ir bendradarbiavimo kultūrą niekada nevèlu. Straipsnyje siekiama atskleisti socialinès kompetencijos svarbą ịsivertinimo procesui. Pristatomas įsivertinimo proceso teorinis pagrindas, modelis, kuris iliustruoja socialinès kompetencijos dalis, susijusias su bendravimu (savitarpiškumu) ir bendradarbiavimu (veikla). Kaip tyrimo objektai pasirinkti ryšiai tarp mokytojų, mokytojo ir mokinio, mokinių, mokinio ir mokytojo, siekiant atskleisti įsivertinimo ir veiklos charakteristikas mokymosi procese. Tyrimas atliktas taikant kiekybinį klausimyną, jame dalyvavo 49 mokytojai ir 142 mokiniai iš Lietuvos, 23 mokytojai ir 86 mokiniai iš Belgijos.

PAGRINDINIAI ŽODŽIAI: socialinè kompetencija, bendravimas, bendradarbiavimas, įsivertinimas.

DOI: http://dx.doi.org/10.15181/tbb.v72i3.1168

\section{Introduction}

Social human being was and is important in all existential epochs. In his life full of diversity, a human is directly linked to other humans from an early age till the end of life. Although every person is innately different, has different characteristics and personality, intellectual ability, emotional expressions of 
faith, efforts, all people have the need for social competence (Key competences for lifelong learning. Recommendation of the European Parlament and of the Council. 2006). Nowadays, the formation of a new twenty-first century society structure, which is changing people's personal, professional and social conditions of existence, more and more frequent are demands from the public and there is a trend of social competence development. First of all, thinking about teachers, who often run initiatives, internal motivation, knowledge, sometimes in interaction with students in strengthening social competence phenomena such as communication and cooperation (Concept Document of the Commission Expert Group on Key Competencies, 2002). It is never too late to improve communication and cooperation culture. The study is based on the principle of comparative analysis of social competence development in the institutions of two countries (Belgium and Lithuania), there are attempts to discuss the research results on social competence, viewed from a European experience. The object of the research - Belgian and Lithuanian teachers and students' social competence.

The aim of the empirical research is to reveal the social competence of Belgian and Lithuanian teachers and students' using a comparative approach and highlighting the self-assessment in learning process.

\section{Self-assessment process}

Communication in our lives takes a very important and significant place, because none of man can live alone. The society would have not been able to survive and live until now, if people had not been communicate with each other, and only thanks to all members of society was formed the present society. The world which is contemporary modern, based on technology, is characterized increased, a perfect society, capable to live together with different nations and ethnic groups, individuals and communities, who are constantly in contact and their relationship is close. This relationship requires mutual tolerance and ability to communicate between different groups of people. It is therefore particularly important to foster young, developing intercultural spirit in them, intelligence, based on wisdom.

Man seeks to communicate with others, not only for surviving, but also live, grow and develop as a person. A. Anzenbacher (1992) believes that in order to develop the communication culture, must be properly explain what is co-operation. This is some way of communication in which two or more persons are able to work together. Cooperation is the ability to work with others. Working together, people have certain goals, they must seek, therefore, must have felt on both sides of the effort to achieve those goals. Necessary to eliminate manifestations of selfishness, in order to achieve common goals, selfishness is the obstacles of common goals. 
The process of learning. Collaboration included in the learning process, thereby creating an environment that allows each student to feel good and be taken. It should be noted that the overwhelming cooperation of individual student performance or activity, in contrast, enhances personal self-esteem, motivation for learning to participate in the learning process. L.Vygotskis state that cooperation is not only intended to facilitate learning but also in cooperation is learned. One can safely say that the cooperation in the learning process is learning to learn strategy. Its core is a single teacher - teacher, student - student activities based on their mutual agreement, relations between them, the overall objectives of achieving a common understanding and approach.

Collaboration oriented to group. J. Dewey's concept of co-operation based on the personal attitude, values and orientations. In his view, the internal motivation of a group of pupils to achieve the common goal of cooperation is a basis cooperation foundation. The essential co-factor is a group of pupils sharing not only targets, but also ideas, thoughts, opinions, beliefs, common goals. The student voluntarily in cooperation with other groups of students, feel the inner need for loyalty to others, because of intolerance or violence to others undermines mutual trust (Piage, 1968). Also J. Piaget in his scientific work emphasizes the fact that the group originated sociocognitive conflict can improve group of student understanding. Lawrence describes the learning group collaboration as a form that allows heterogeneous group of low-achieving general education goals, based on interactions that encourage each student group to actively participate in joint activities of the task. Learning in groups it is social competence development, which is necessary for learning to solve problems together. The Group's activities are achieved and acquired the important characteristics: one of them - ability to listen to one another to provide assistance, support and reinforce one another, and secondly - the joint activities, sharing of responsibility for a common goal.

The education system, like all social systems, as well as those actions is based on coordination of joint objectives. Of course for personality development is needed cooperation with other groups and individuals or public institutions. In this process, the person is not a passive observer. He is responsible for its sophistication, dynamism and autonomy. In summary, the teaching mission of the learning process, predicated on co-operation is like a director: Develop scenarios of cooperation; Provide learning objectives, discussion topics; To promote the learning objectives; To develop an independent self-assessment.

Teacher and student participation in the process of selfassessment. One of the methods which can develop teachers social competence is self-assessment procedure. This procedure can be applied as a professional and a personal assessment tool that includes strong social competence sides. In such 
self-assessment teachers can identify areas of improvement priorities, to better understand you as a person and a professional teacher. This approach makes a critical look at ourselves and together they can serve as a tool for professional development.

Student self-assessment is important for the whole learning process, their motivation, and follow-up. Student self-assessment should: respond to the development and growth characteristics; provide information about strengths and weaknesses of the development directions; to promote teaching / learning process development and improvement; develop adequate skills for yourself and your assessment; be related to the purpose of outlining a sense of achievement and progress (Fig. 1).

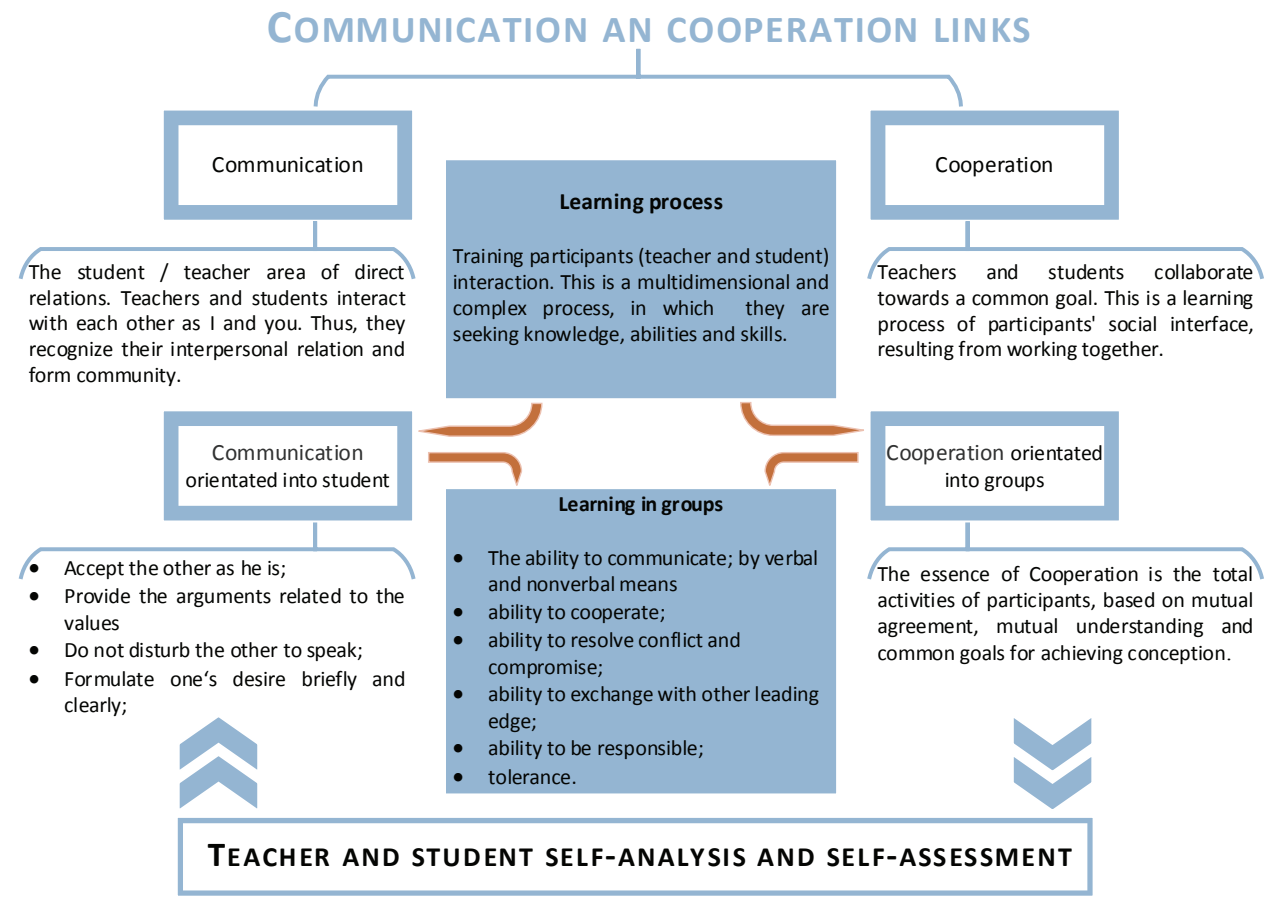

Figure 1. The process of self-assessment

Self-assessment is used in student activities process. The student through selfassessment can describe its perceptions, to reflect on their strategies, compare together approaches. There are three forms of participation in the evaluation process: self-assessment (narrow sense), the mutual evaluation and overall evaluation (Fig. 2). 




Fig. 2. The form of student self-assessment process

The links / relationships between these three forms of self-assessment (selfevaluation, mutual-evalutation and overall-evaluation) ensure that students' participation in the teaching/ learning process is dynamically regulated by changing teacher training methods. It is recommended to plan and to implement a mutual evaluation and co-assessment forms, combining self-evaluation and preparing recommendations for student's change and development. In other words, the student self-assessment is the beginning of an interactive participation in the teaching / learning process.

Teachers' self-assessment. Teachers may think that assessment takes time and gives a little benefit. We should believe self-assessment benefit for the teacher. It helps to know what questions to ask students about their assessment activities, as well as their attitudes about relationships, support each other.

Teachers' self-analysis is characterized by a four-step cycle (Bresciani Marilee, 2007):

- Looking at yourself, self-understanding and strengthening. It is thoughts, actions, attitudes, values and feelings identification, analysis and rethinking.

- Situations in which teachers work, analysis. Analysis of the situation related to the knowledge of the essential factors, i.e. who was causing a number of reactions and responses in certain situations.

- Raising questions and challenges. This is related to the search for meaning, a new approach to certain situations. Raising questions and challenges leads teachers to deepening understanding.

- Synthesis with a new understanding and discovery of the meaningfulness of their activities. The newly updated meaningfulness activity promotes teacher behavior, thoughts, feelings, values, attitudes and development. This cycle can be represented as follows (Fig. 3). 


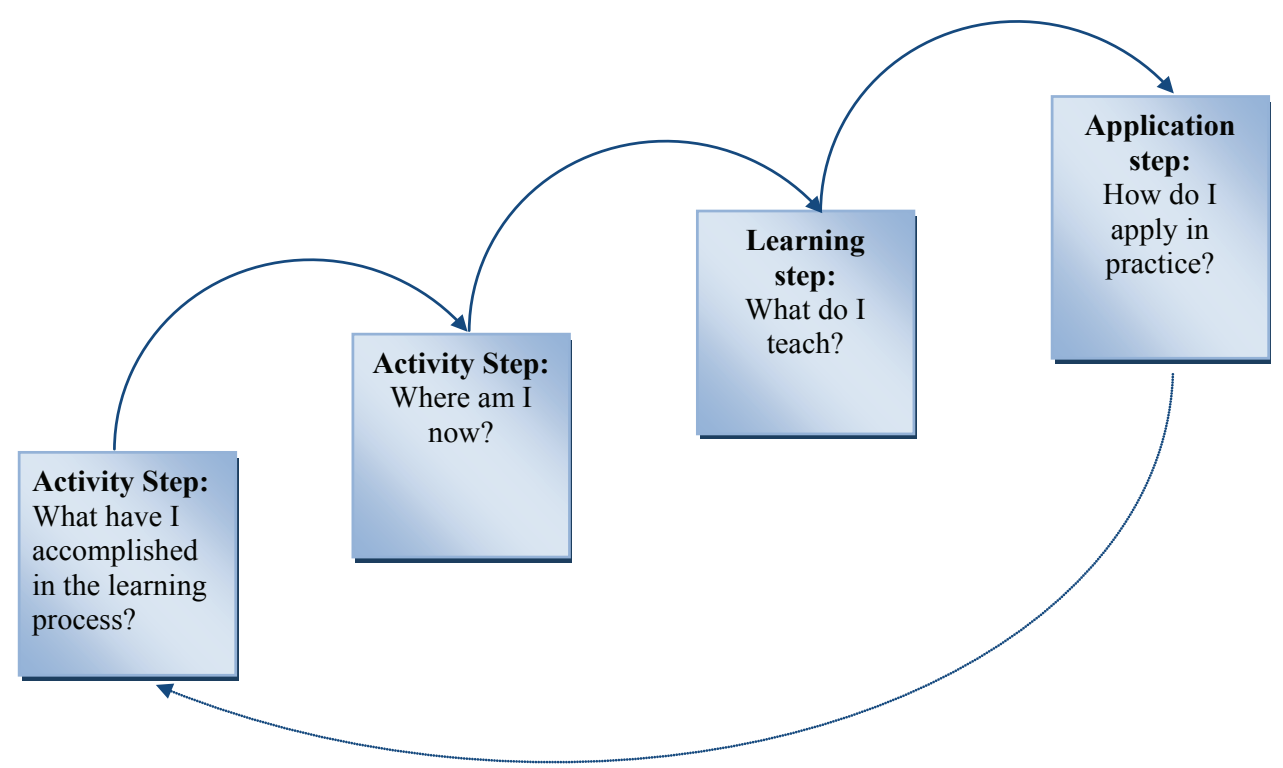

Fig. 3. Self-assessment process cycle

Self-assessment may lead to new skills, new knowledge. Of course, speaking about teacher social competence is not enough just to talk about his skills, abilities and knowledge. In the concept of competence lie deeper things - a valuable basis of participating, personal characteristics, attitudes and so on. It is therefore important to answer the question, what personal characteristics teachers must have. Or what kind of certain skills should have students preparing to learn a certain subject. A new analysis of learning and reflection about their experience in adapting to existing personal understanding, skills, qualities and attitudes help to translate a learning to a higher quality and/or professional activities.

By participating in the learning process students help to realize each other's needs and express them freely to think and create. Communication and cooperation in cultural development emphasized in a manifold context. The development of the culture is marked by traditions and innovations, the general origins of cultural interaction, cooperation of the international language of communication in the context of the level of society. Therefore, communication and cooperation skills and their development is a component of social competence. Communicating and acting teachers and students can share experiences with each other, teach each other, to make proposals on how to improve the learning process. 


\section{The Method}

This questionnaire has a column usually filled by the teacher, but we added a lot of new questions. The questionnaire consists of 3 parts: The questions of the 1st part are closely related with the gained competences: communication and collaboration. These competences are used in two different levels of relations: interrelation between student - student and teacher - student and reciprocity between student - teacher and teacher - student. We have decided to divide these questions according to the offered relations student - student and teacher - student in 2 ways. The first communicative dimension with 20 questions by choice: strongly agree, agree, neither agree nor disagree disagree, strongly disagree.

The $2^{\text {nd }}$ part of the questions is related with the dimension of collaboration. In this case, we have given 10 possible answers with the above mentioned variants of the answers. These are the questions about the reciprocity of student - teacher, teacher - student. There are also 20 variants of responses about the communicative competences; and 8 about the collaboration with the same choices. The second group of questions inquired about the methods teachers used in a usual lesson. We have given 11 choices: always, often, sometimes, never, no answer.

Another question is about active teaching methods with the responses: strongly agree, agree, neither agree nor disagree, disagree, strongly disagree.

The last question is about active teaching methods used by the teacher in the class. We have offered 5 possible answers: always, often, sometimes, never, no answer. The teachers were asked about the competences that should be educated in order to improve communication and collaboration at school. 9 responses were offered.

In the 3rd and the last group of questions, students' personal data were given: age, nationality, sex. And also about the teachers: the level of teaching, work experience, age, nationality and sex.

The questionnaire for the students was filled in different professional groups.

\section{Respondents}

In order to reveal social competence, there is an offered model which illustrates the parts of social competence such as communication (reciprocity) and collaboration (activity). Thus, in order to reveal social competence in using media technologies, there have been chosen research subjects: teacher-teacher; teacherstudent; student-student; student-teacher which reflect the characteristics of reciprocity and activity in the process of learning. The instrument of the research 
is a questionnaire. In the inquiry there were 49 Lithuanian teachers, 142 students and 23 Belgian teachers and 86 students.

For practical purposes, we have used the questionnaire for students and teachers in 2 different schools - one of them is in Lithuania, the other in Belgium. The total number of respondents -300 .

\section{Discussion of the results}

The interaction in activities

A man as a social being and is tied to other people. While being social active there is a natural need to know and understand by building up contacts and developing interrelations. In such a form collaboration is established and relations of communion are developed. There are dominations of formal and informal people gathering. What about proceeding in formal group activities, especially students, who are constantly in a close social relation and united by common interest learning.

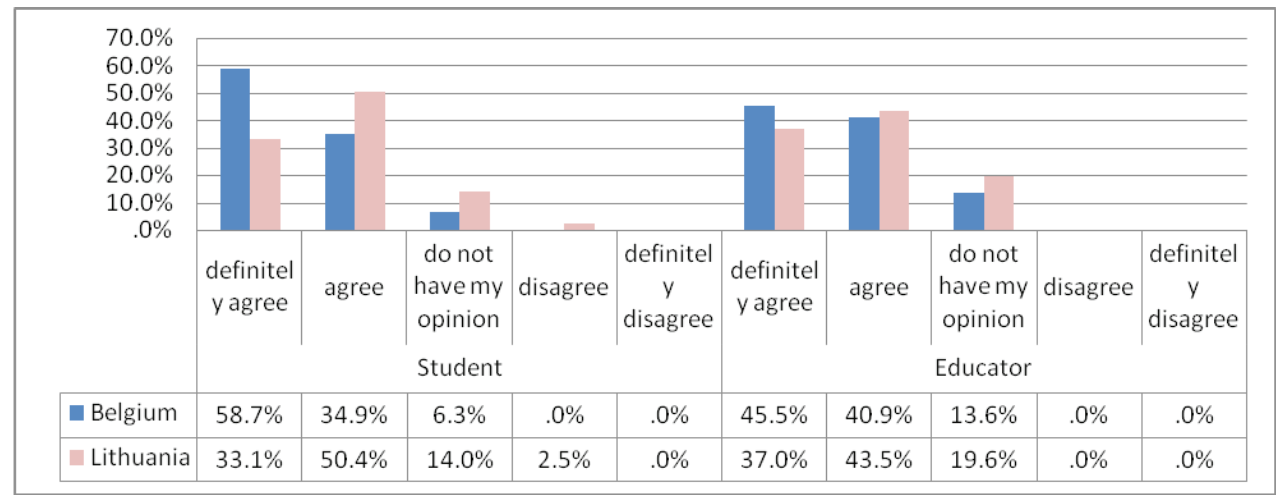

Fig. 4. We call each other names

We will discuss the results of the interaction between teachers and students who study in two countries (Belgium, Lithuania). In both of the countries, teachers and students were given a questionnaire that helped to reveal the success of the interaction activity among respondents.

While comparing the average results of the two countries, it is clear that less students in Lithuania comparing to Belgium (33.1\%) and less teachers (37.0 \%) definitely agree, that they call each other names. More students $(50.4 \%)$ and $(43.5 \%)$ teachers in Lithuania than in Belgium agree with the fact, that "they call each other names". The results show that more Belgian students call each other names (58.7\%) than Lithuanian students (50.4\%). Very clear assertion of definitely 
agree is expressed by Belgium teachers $(p<0.000)$ and students $(p<0.000)$. This firm difference is validated by obtaining statistically significant reading. Other differences between the results are not so clearly distinguished, though you can see 4 figure.

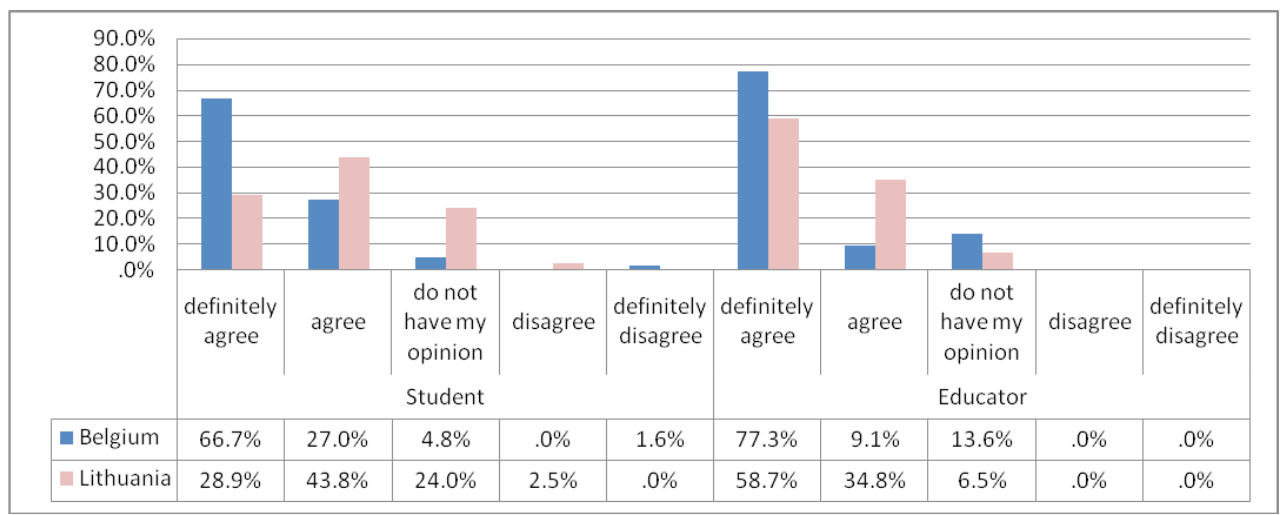

Fig. 5. We respect each other

The results of the question "How we respect each other?" were unevenly divided between the countries. In the figure 5 Belgium the results show, that $66.7 \%$ students definitely agree with the proposition that they respect each other. $77.3 \%$ of Belgium teachers say that they definitely agree with this statement. $27.0 \%$ Lithuania students and $9.1 \%$ teachers agree with the fact, that they "respect each other". Only $4.8 \%$ students and $13.6 \%$ teachers do not have opinion about this assertion. $1.6 \%$ students definitely disagree with the proposition that "we respect each other". Less students (28.9\%) and teachers (58.7\%) in Lithuania than in Belgium definitely agree that they respect each other. But more students $(43.8 \%)$ and teachers $(34.8 \%)$ agree with this fact. In Lithuania more students (24.0\%) and more teachers $(6.5 \%)$ than in Belgium have no opinion about respect to each other. $2.5 \%$ students disagree with the fact that "we respect each other". It is interesting to mention that more Belgian students and teachers definitely agree that they respect each other. But in Lithuania more students and teachers agree with this fact.

The analysis of the question We say to each other compliments is differentiated equally. Belgian and Lithuanian students and teachers understand the ability to communicate while using compliments more or less in the same way.

The research results reveal that only $12.7 \%$ Belgium students definitely agree that they say each other compliments, $42.9 \%$ agree and even $39.7 \%$ don't have their opinion about that. $3.2 \%$ students disagree that they say each other compliments. $1.6 \%$ Belgium students definitely disagree with the fact that they 
say compliments to each other. $31.8 \%$ Belgium teachers definitely agree and $40.9 \%$ agree with the affirmation that they say compliments to each other. $22,7 \%$ teachers do not have opinion about that and $4.5 \%$ teachers disagree with the idea, that they say compliments to each other.

Lithuanian students less $(14.0 \%)$ then teachers $(30.4 \%)$ definitely agree that they say compliments to each other. The conclusive results between students and teachers inside particular country is of high statistical significance level $(p<0.01)$. The research results reveal that $42.1 \%$ students and $37.0 \%$ teachers agree with it and this result is close to the answers of Belgium students and teachers. About $32 \%$ of Lithuanian students and teachers have no opinion about that. Even 10, 7 \% students, more than in Belgium, disagree and think that they don't say compliments to each other. The results show that there are enough students and teachers who have no opinion about saying compliments to each other. There are more teachers in Lithuania than in Belgium, but less students, who have no opinion about this fact (Fig. 7).

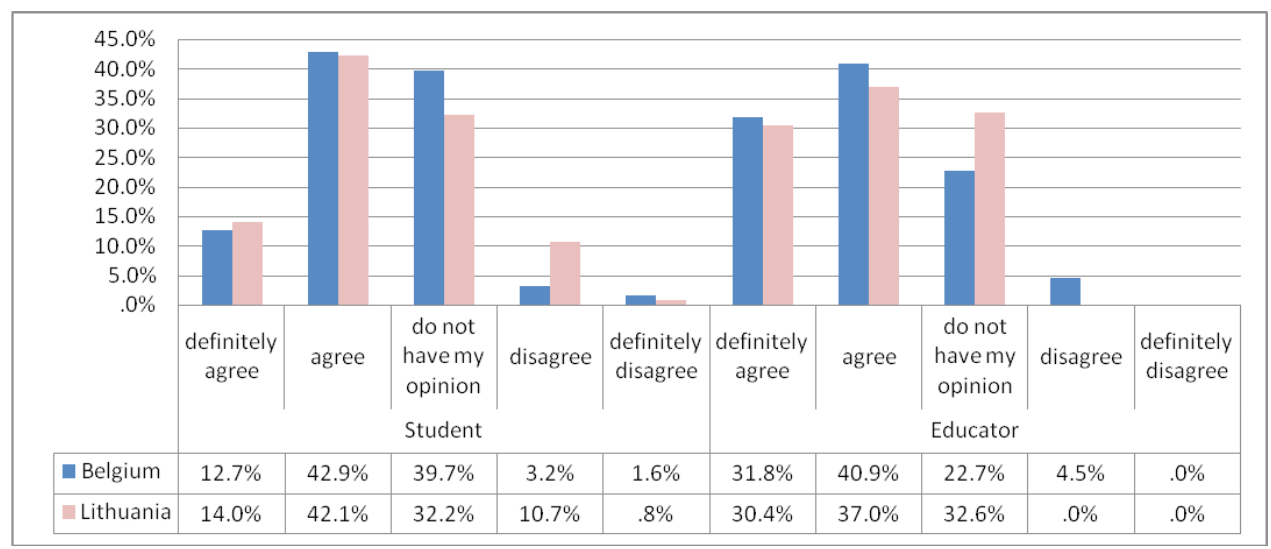

Fig. 7. We say to each other compliments

The question of interrelation Share and provide help to each other results between the countries had various divisions. Belgium students and teachers support the firm proposition"definitely agree" Belgium students (47.6\%) and teachers $(63.6 \%)$ more than Lithuanian colleagues $-16.5 \%$ and teachers $-43.5 \%$. The significant difference of the aforesaid proposition between countries statistically equals $-p<0.000$. The completed analysis between teachers from different countries showed that although numbers in some cases are different there is no significant distinction in statistics $-p>0.20$.

Still the results regarding other propositions are divided differently. However, the following parameter spotlight the firm approval of Lithuanian students and teachers of the term "agree". Other results can be found in figure 8 . 
THE DEVELOPMENT OF SOCIAL COMPETENCE OF TEACHERS AND STUDENTS:...

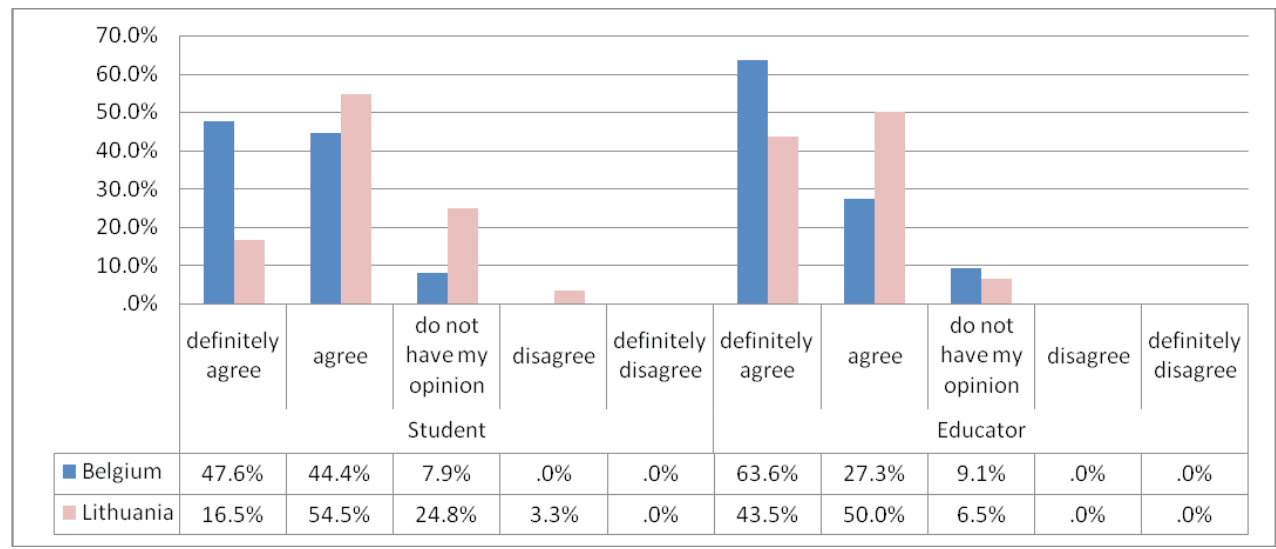

Fig. 8. Share and provide help to each other

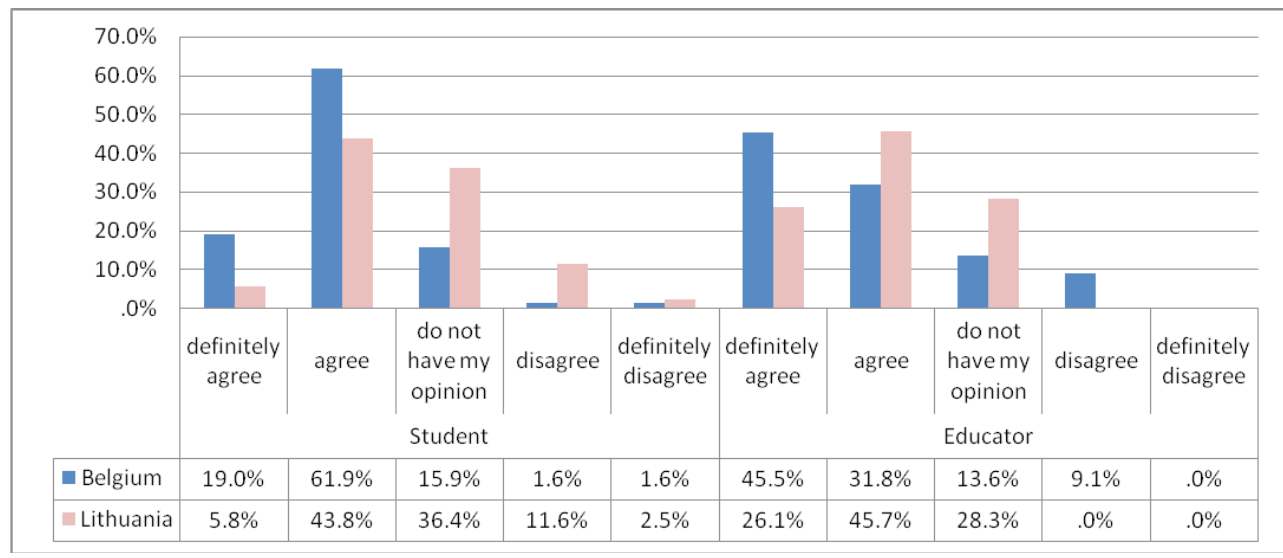

Fig. 9. We can able to stay the other shoes, to empathize with the other

Question „We are able to stay in the other shoes, to empathize with the other" revealed a great variety of opinions in both of the countries and groups of teachers and students.

The results about staying the other shoes, empathizing with the other are shown in the 19 figure. $45.5 \%$ teachers definitely agree and $31.8 \%$ agree with the statement that they can be able to stay the other shoes, to empathize with the other. $13.6 \%$ do not have opinion about that and $9.1 \%$ disagree with this statement. $19.0 \%$ students definitely agree and $61.9 \%$ students agree, saying that they can be able to stay the other shoes, to empathize with the other. $15.9 \%$ students do not have their opinion about that. $1.6 \%$ students disagree and $1.6 \%$ definitely disagree with the statement, that they can be able to stay the others shoes, to empathizewith the other. 
$45.7 \%$ teachers agree, that they can be able to stay the other shoes, to empathize with the other and $43.8 \%$ students agree with that, too. $26.1 \%$ teachers and $5.8 \%$ students definitely agree about that. About $36 \%$ students and $28 \%$ teachers do not have their opinion. $11.6 \%$ students disagree and $2.5 \%$ students definitely disagree that they can be able to stay the others shoes, to empathize with the other.

Comparing Belgian and Lithuanian situation it is interesting to mention that more students in Belgium than in Lithuania agree that they are able to stay in the other shoes, to empathize with the others (Fig. 9). The statistical level $(p<0.000)$ clearly indicates the difference between Belgian and Lithuanian students.

\section{Conclusions}

1. Learning based on experience has become a very important learning factor as individual has to be able to use his knowledge in constantly changing surroundings. Therefore it is very important to be able to assess such skills and abilities, as cooperation and communication with other persons (teacher, learner), their groups, to establish and develop interpersonal relations, to find compromises, to solve conflict in constructive way, to learn for work and to create together with other persons, to help them, to persuade and to involve them in implementation of common goals. It was found that the teacher's vocational development depends on the analysis of his experience and intensivity of thinking. There are numerous examples of such learning not only in vocational activity of an individual, where it is of utmost importance as it helps in designing vocational career and study plans, but also in social and societal life as helps an individual to integrate into complex social and societal context and even influence it; consequently, it reflects the component of citizenship in a broad sense. To sum up, it is possible to state that with the spread of learning technologies, special attention should be paid to the education of values, and social competence is one of them. Therefore, it is very important to root skills: to get on well with other persons (teachers, students), their groups, keep up interpersonal relations, find solutions, solve conflicts constructively, work and create together with other persons, help and inspire in seeking for common goals. In order to socialize in his/her environment, a person from his early years has to be among people, communicate, learn to cooperate, to be empathic, acknowledge another person.

2. The conducted empirical research confirmed that social competence is included into the activity competence model. Activity competence theoretical construct combines into a complex system intellectual skills, knowl- 
edge of a particular area, cognitive skills, strategies, social behaviour. Hence, we may conclude social competence reveals through activities and learning. Social competence is vitally important for a young person seeking to become independent, able to be a competent citizen. The research shows that self-assassment gives learners with necessary skills: to cope with challenges, maintain and develop friendly relations, be efficient in learning process, contributing to the group and community activities.

3. Communication is described as meaning creation and sharing process which is perceived as having verbal and non-verbal aspect. Effective communication with peers is associated with successful development of friendship.

Received 20150813 Approved for publishing 20151005

\section{References}

Anzenbacher, A. (1992). Filosofijos ịvadas. Vilnius: Katalikų pasaulis.

Bresciani, M. J. (2007). Assessing student learning in general education. Good practice. Case studies. Anker publishing company, inc. Bolton, Massachusetts.

Černius, V. J. (2007). Organizacija. Grupé. Individas. Kaunas: Pasaulio lietuvių kultūros, mokslo ir švietimo centras.

Černius, V. J. (2006). Žmogaus vystymosi kelias. Kaunas.

Gilbert, R., Bullati, J., Turner, P., Whitehouse, H. (2004). The generic skills debate in research higher degrees. Higher Education Research \& Development 23, 3.

Key competences for lifelong learning. Recommendation of the European Parlament and of the Council. (2006). Available at internet: http://eur-lex.europa.eu/LexUriServ/site/en/oj/2006/1_394/1_39420061230 en00100018.pdf

Mill, J. S. (1995). Apie laisvę. Vilnius: ALK pradai.

Schmuck, R. A., Schmuck, P. A. (1988). Group Processes in the Classroom. Dubuque: Wm. C. Brown Company. Teresevičienė, M., Gedvilienè, G. (2003). Mokymasis grupèse ir asmenybès kaita. Monografija. Kaunas: VDU.

The definition and Selection of key Competencies. (2005). Executive Summary. OECD. 
